\title{
A Study of Translation Strategies of Animated Film Titles from the Perspective of Eco- translatology
}

\author{
Yue Wang \\ Shanghai International Studies University, Shanghai, China \\ Xiaowen Ji \\ University of Shanghai for Science and Technology, Shanghai, China
}

\begin{abstract}
In recent years, the animated film industry is booming and attracting more and more attention. This study, under the guidance of Eco-translatology, revolves around both E-C and C-E animated film title translation, analyzing its translational eco-environment and three-dimensional transformations. Use of main translation strategies of animated film titles, which are transliteration, literal translation, free translation and creative translation, is analyzed. It is found that free translation is the mainstream in both C-E and E-C translation of animated film titles while that creative translation is the least frequently used method.
\end{abstract}

Index Terms -Eco-translatology, animated films, film title translation

\section{INTRODUCTION}

With the advance of globalization and China's reform and opening-up policy, films, as a cross-cultural communication medium, are playing an increasingly important role. Nowadays, animated films, an essential branch of the film industry, are being paid more and more attention to. Not only have a large number of premium English animated films flood into the Chinese film market, but some high-quality Chinese animated films are also released and highly acclaimed by the audiences. As the "face" of a film, a film title is a summary and refinement of the film content. It is the key to catching the eyeballs of the audiences and making them remember the film. Therefore, the translation of film titles has a strong guiding effect and is of great research value.

There are lots of studies on film title translation, including the application of different theories to this field and the analysis of translation strategies. So far, however, few studies on animated film title translation have been conducted. Among those existing ones, few have analyzed it from a macroscopic angle or proposed a systematic theory to guide both E-C and C-E animated film title rendering. Therefore, this study is going to concentrate on animated film title translation from the perspective of Eco-translatology, a relatively new and systematic translation theory proposed by the Chinese scholar Hu Gengshen (2001), and tries to find out the frequently adopted translation strategies. The main purpose of this study is to provide some guidance and reference for the translation of Chinese and English animated film titles, so as to attract more scholars to pay attention to this field.

\section{ECO-TRANSLATOLOGY}

Before Eco-translatology, many scholars have made translation studies from the perspectives of "ecology", "environment", "selection" or "adaptation". According to Newmark (1982), the focuses of translation theory are not on the translation principles of source text or target text, but on selections and decisions in the source text. In 1900, Lefevere and Bassnett (1990) raised the issue of cultural turn, equating the translation context with the cultural environment. Michele Cronin (2003), in his book Translation and Globalization, first proposed "translation ecology" and suggested that translation between languages should maintain a "healthy balance".

In 2001, Eco-translatology was first put forward by Hu Gengshen (2001), a distinguished domestic professor who has made the most remarkable achievements in this research. It is an emerging eco-translation paradigm of translation studies from ecological perspectives (Hu Gengshen, 2013). With metaphorical analogies between the translational ecosystem and the natural ecosystem, conceptual borrowings and eco-holism as its methodology, Eco-translatology probes into translational eco-environments, textual ecologies, and "translation community" ecologies, as well as their interrelationships and interplays (Hu Gengshen, 2013).

$\mathrm{Hu}$ (2008) defines translation as "a selection activity of the translator's adaptation to fit the translational ecoenvironment". At the micro level, the translation process is described as alternate cycles of the translator's adaptation and selection (Hu Gengshen, 2013). The translational eco-environment refers to the world of the source text and the source and target languages, comprising the linguistic, communicative, cultural, and social aspects of translating, as well as the "translation community", namely the author, client, and readers (Hu Gengshen, 2013). These factors can 
restrict the translators' best adaptation and optimized selection. "Translator-centeredness" is a core notion of the theory, which highlights the initiative and subjective role a translator plays in the translating course. His or her adaptive selection and selective adaptation give rise to the optimal translation. The translation strategies are generalized as "three-dimensional transformations" operating at the micro (linguistic, cultural and communicative) levels. In general, the more dimensions the translator adapts to, the more appropriate the selection will be.

\section{TRANSLATIONAL ECO-ENVIRONMENT OF ANIMATED FILM TITLE TRANSLATION}

\section{A. Characteristics of Animated Film Titles}

With a creative and imaginative tendency, animated films have colorful dynamic pictures, pure and interesting cinematic images, and fantasy stories, which make them distinct from other film genres. Having a full understanding of characteristics of the target text is helpful to the translator's adaptive selection and transformation. Similarities and differences between Chinese and English animated film titles will be discussed below.

\section{1) Similarities}

Chinese and English animated film titles are simple and concise. Since most animated films are named by main characters, the plot or theme, people can directly get important information about the film from the title. It is an effective way to arouse their interest to go to movies and explore the details. The film titles also feature the elements of fantasy and adventure. Many films use the words like “奇缘 (qi yuan)”, “冒险 (mao xian)”, “wonder” and "adventure"which embody the feature of animated films as well as appeal a lot to children and teenagers.

2) Differences

One difference is that Chinese animated film titles pay attention to images while English ones prefer directness (Wang Hongxi, 2019). Under the influence of Chinese culture, images and aesthetic conceptions are employed in this art form. Such film titles like “昨日青空(zuo ri qing kong)”, “钟馗传奇之岁寒三友(zhong kui chuan qi zhi sui han san you)”, and “幸福路上(xing fu lu shang)”can bring endless aftertastes to viewers. “Crystal Sky of Yesterday” of 《昨日 青空(zuo ri qing kong)》 refers to lost youth, well indicating the theme. On the contrary, English animated film titles are inclined to present information directly to stimulate the audiences' curiosity. Moreover, Chinese and English animated film series have different forms of film titles. Many animated films are a series, such as 《熊出没(xiong chu mo)》, 《猪猪侠(zhu zhu xia)》, Marvel Rising and How to Train Your Dragon. Due to the success of the previous one, the film producer is likely to create another one of the series. The form of Chinese ones is "main title+ 之+ subtitle”, like “猪猪侠之英雄猪少年(zhu zhu xia zhi ying xiong zhu shao nian)”, while the form of English ones tends to be "main title+ colon+ subtitle", such as "Marvel Rising: Heart of Iron", and "How to Train Your Dragon: The Hidden World". But there are a few exceptions. A case in point is that the name of Wreck-It Ralph II is "Ralph Breaks the Internet".

\section{B. Functions of Animated Film Titles}

The prime principle of Functionalism is that the translation should be oriented to the potential function of the target text (Nord, 2006). There is no doubt that functions of film titles have influence on the translator's selection and adaptation, so they are deemed as the part of the translational eco-environment in this paper. According to He Ying (2001), the major functions of film titles can be categorized as follows: (1) informative function, (2) expressive function, (3) aesthetic function, (4) advertising (commercial) function. In the process of translation, the translator should consider whether the title contains the main message of the animated film, sets the film's atmosphere to attract audiences, has aesthetic features and meets the commercial requirements.

1) Informative Function

The informative function is to inform the potential audiences of some facts and relevant information about the film, such as main characters, settings or the plot. With the help of the title, the audiences can get a rough picture of the story or even the theme. Since animated films are mainly aimed at children and teenagers, the title should be simple and easy to understand. Examples are “巧虎大飞船历险记(qiao hu da fei chuan li xian ji)”, “哪吒之魔童降世(ne zha zhi mo tong jiang shi)", "Sgt. Stubby: An American Hero" and "The Death and Return of Superman". People can immediately get the information at the first glance of the film title and then consider whether to buy the tickets.

2) Expressive Function

The expressive function of film titles is to set the keynote, tone or atmosphere of the whole film, such as the lyrical, thrilling or comedic one, so that spectators would feel attracted and be interested to see the films. To give the examples, the animated film titles with “奇缘(qi yuan)" successfully create the unique and magical atmosphere of the films, and those with “总动员(zong dong yuan)” make audiences conjure up the picture of a crazy adventure with all characters involved.

3) Aesthetic Function

Film is an art form, presenting beautiful pictures and bringing aesthetic enjoyment to viewers. A highly-acclaimed film title should also perform the aesthetic function, which requires the title to involve aesthetic elements such as musical words, the proper language style, vivid images and rhetorical devices. When it comes to animated films, the 
title should entail beauty of imagination, appealing to children and teenagers. For instance, “昨日青空(zuo ri qing kong)” and “作式青春(si shi qing chun)” are of the four-character structure and have delicate words. Before seeing the films, people will have got a vivid picture of stories taking place in youth and conjure up their own memories of yesterday. Such feeling can lead people to the cinema. The color and force of the words can always increase elegance and power to the film title.

4) Commercial Function

It is known to all that the cost of film making is extremely high, so the ultimate purpose of a film is to achieve its commercial purpose. The film title, like a trademark or advertisement of the film, has to meet the requirements of the market and target audiences, giving full play to commercial publicity in order to maximize the box office. The commercial or vocative function of animated film titles is to "call on" people to see the film, trigger off their interest and have the tickets sold.

\section{Ideology of Societies}

How people think of animated films is quite important to the development of the industry, so the ideology of societies is definitely one component of the translational eco-environment. Since this study focuses on the translation of Chinese and English animated film titles, here the societies refer to the Chinese and western societies.

The western world has a longer development history of animated films than the Chinese society. With the growth of science and technology, animation was poised for a great leap forward. Historically and technically, the first animated film was Humorous Phases of Funny Faces (1906), made by J. Stuart Blackton. Then a large number of great animators, animated film studios and companies sprung up, making priceless contribution to the industry. Examples like Disney, Pixar and DreamWorks all produced excellent works, coloring the childhood of countless people. Lots of iconic cartoon characters, such as Mickey Mouse, Snow White and Superman, as well as the positive values conveyed by the films are deeply imprinted in people's mind. More and more animated films are translated into different languages and introduced to various countries.

In China, however, the country's first animated film, Princess Iron Fan, was created in 1941 by Wan Guchan, and his brother, Wan Laiming. Afterwards this new genre of film was paid increasing attention. Due to the policy of reform and opening up, many premium foreign animated films are introduced, and also an increasing number of Chinese animators start their own creation, hoping to display their works to the whole world. In this period, the public start to have some ideological changes and gradually accept the values, culture, and ideas embodied by these imported films, and their cultural confidence in Chinese animation is enhanced.

In fact, people of both western and Chinese societies share the same concern for humanity and philosophy of life. Viewers enjoy experiencing love, affection, friendship, etc., and are glad to know about the information of other countries. To conclude, the source language society hopes to propagate culture and values as well as make the film popular. Audiences of the target language society want to enjoy the film and get some knowledge about the outside world. Therefore, when translating animated film titles, translators should take ideologies of both societies into account.

\section{The Translation Community of Animated Film Title Translation}

The "translation community" refers to a collection of "people" related to a particular translation activity (Hu Gengshen, 2013). The representative of the "translation community" is the translator. Others like the author, readers, critics, reviewers, publishers, marketers, sponsors are also involved.

Li Qun (2002) classifies film title translation as advertising translation with the only purpose to earn profits. In order to meet the commercial requirements, the film has to cater to the target audiences so as to maximize the box office (Li Qun, 2002). The target audiences of animated films are, but not limited to, children and teenagers. Since most people see animated films for pleasure and excitement, the translated titles should be attractive and interesting. Elements of fantasy or exaggerated words can be used.

Another essential part of the "translation community" is the film producer who takes charge of the film production. The decision of film title is in its hand. As the investor, the film producer is also the main beneficiary of the film's box office and copyright revenues. Therefore, the translated animated film titles should contain the ideas film makers try to express and satisfy commercial requirements.

\section{ANimAted Film Title TrAnSLATION FROM THE PERSPECTIVE OF ECO-TRANSLATOLOGY}

"Transplanting" texts at multi-dimensional levels is a major eco-translation method. Three dimensions are mainly focused on, which are linguistic, cultural and communicative dimensions. The transformation from linguistic dimension requires the translator to accurately grasp the linguistic form in the translation process. The transformation from cultural dimension means that the translator should pay attention to the transmission and interpretation of the cultural connotations of the source language and target language. The transformation from communicative dimension mainly refers to the realization of the translator's communicative intention. In fact, in the translation process, the three dimensions and other factors are interwoven and all at play. Therefore, analysis from a single dimension doesn't mean that other factors don't have effect on the translation. Examples used in one dimension could also be applied into other discussions, so it's inevitable that some examples will appear more than once. This study selects a research sample, and 
the translator's adaptive selection and transformation in terms of each dimension based on the sample will be analyzed.

\section{A. Research Sample: Chinese and English Animated Film Titles Collected from Douban}

The research sample used in this study consists of 43 Chinese animated film titles and 94 English ones and their corresponding translated titles, collected on Douban, a Chinese website providing information of books, films and music. These films are released from 2017 to 2019 and rated 5.0 and above by Douban users. The film rating mechanism of Douban is divided into two steps. Firstly, people rate by giving stars, one star indicating "incredibly bad", two stars "bad", three stars "okay", four stars "recommended", and five stars "highly recommended". Secondly, the backend converts the stars to points (0-10). It can be said that animated films with a score of 5.0 and above in the past three years are relatively new, and are accepted and recommended by most of the audiences. Their titles are of more conference and research value than those of films with lower scores. That's why these Chinese and English animated films are selected as the sample of the study.

\section{B. Adaptive Selection and Transformation from Linguistic Dimension}

\section{1) Length of Film Titles}

a) E-C Translation

Domestic films prefer four-character expressions as titles. According to Chinese people's language habits, fourcharacter structure is classic and beautiful, so Chinese viewers are more used to this symmetric or rhyme language characteristic and can be easily attracted by such titles. Based on the sample, about $77 \%$ of the source titles consist of at least four Chinese characters. Therefore, translators tend to consider this linguistic feature when doing E-C translation.

\section{b) C-E Translation}

As mentioned above, one of the characteristics of English animated film titles is their pursuit of directness and conciseness. It is quite common to find the titles with only 1 to 3 words. In these cases, names of the characters and plots of the stories are often chosen as the basis of the titles. Hence, compared with E-C translation, C-E rendering focuses more on information delivery.

Examples are displayed in Table I.

TABLE I.

Examples Of Adaptive Selection And Transformation From Linguistic Dimension Concerning Length Of Film Titles

\begin{tabular}{|c|c|c|c|}
\hline Source text & Target text & Source text & Target text \\
\hline Tangled: Before Ever After & $\begin{array}{c}\text { 魔发奇缘: 幸福前奏(mo fa } \\
\text { qi yuan: xing fu qian zou) }\end{array}$ & 玩偶奇兵(wan ou qi bing) & T-Guardians \\
\hline The Breadwinner & 养家之人(yang jia zhi ren) & 西幽玹歌(xi you xuan ge) & Thunderbolt Fantasy \\
\hline Despicable Me 3 & $\begin{array}{c}\text { 神偷奶爸(shen tou nai ba) 3/ } \\
\text { 卑鄙的我(bei bi de wo) 3 }\end{array}$ & $\begin{array}{c}\text { 神秘世界历险记(shen mi shi } \\
\text { jie li xian ji) } 4\end{array}$ & Yugo \& Lala IV \\
\hline Suicide Squad: Hell to Pay & $\begin{array}{c}\text { 自小队: 严厉惩罚(zi sha } \\
\text { xiao dui: yan li cheng fa) }\end{array}$ & $\begin{array}{c}\text { 钟馗传奇之岁寒三友(zhong } \\
\text { kui chuan qi zhi sui han san } \\
\text { you) }\end{array}$ & Judge Zhongkui \\
\hline Gnome Alone & 花园精灵(hua yuan jing ling) & $\begin{array}{c}\text { 猪猪侠之英雄猪少年(zhu } \\
\text { zhu xia zhi ying xiong zhu } \\
\text { shao nian) }\end{array}$ & GG Bond: Guarding \\
\hline
\end{tabular}

2) Part of Speech

a) E-C Translation

Compared with nouns, sometimes verbs are preferred by the Chinese, for verbs can bring dynamics and vividness to film titles. Therefore, English noun phrases can be replaced by verb ones in the translation process, which is a good way to enchant the animated film titles. For example, “Spies in Disguise" is translated into “变身特工(bian shen te gong)" instead of “伪装的特工(wei zhuang de te gong)”. The verb “变身(bian shen)” means transformation, injecting vigor and vitality into the title. Another example is "Luis \& the Aliens" that is translated as “三俊闹地球(san sha nao di qiu)". Actually this target text learns from “三俊大闹宝莱坞(san sha da nao bao lai wu)”, the Chinese name of 3 Idiots, a popular Indian film. The added verb phrase “闹地球(nao di qiu)” points out the place where the story takes place and vitalizes the source text, leaving a lot to the imagination.

\section{b) $\quad$-E Translation}

However, nouns are quite common in English film titles. According to the sample, 88 out of 94 English animated film titles are noun phrases or words. When it comes to C-E translation, verb phrases of Chinese titles tend to be transformed to nouns. Examples are “哪吒之魔童降世(ne zha zhi mo tong jiang shi)” translated as "Nezha: Birth of the Demon Child”, and “大闹西游(da nao xi you)”as “Monkey Magic” or “Adventure in Journey to the West”.

\section{Adaptive Selection and Transformation from Cultural Dimension}

Due to the differences in nature and content of the source text culture ecology and target text culture ecology, translators should not only pay attention to language transformation, but also adapt to the whole cultural system. They are required to consider the transmission of two languages' cultural connotations as well during the translation process. 
Basically speaking, when translating animated film titles, translators should have cultural consciousness and fully understand the content and background of the films, trying to overcome the barriers caused by cultural differences and maintain harmony and equilibrium of the both culture ecologies. Only in this way can the translation embrace the most natural and familiar expression, and be completely accepted and understood by the target audiences.

1) E-C Translation

The use of traditional Chinese cultural elements is particularly frequent during the process of rendering English animated film titles. For instance, the titles of the blockbusting films Batman and Spiderman are translated as “蝙蝠侠 (bian fu xia)” and “蜘蛛侠(zhi zhu xia)” using the same Chinese character “侠(xia)”. Batman and Spider are all super heroes saving the world, and “侠(xia)" in Chinese embodies the deep rooted chivalrous spirit of them. Such expression seems more familiar and attractive to Chinese viewers. This strategy is also adopted by Lego DC Comics Super Heroes: The Flash (《乐高 DC 超级英雄: 闪电侠 le gao DC chao ji ying xiong: shan dian xia》), Wonder Woman: Bloodlines (《神奇女侠: 血脉 shen qi nv xia: xue mai》) and other animations. Another good case in point is “超人 王朝(chao ren wang chao)", the Chinese title of Reign of the Supermen, the sequel of American animated film The Death of Superman. The story is about several new characters presenting themselves as possible successors after the death of Superman. “王朝(wang chao)" means dynasty in Chinese with the indication of power and rule. Translating “reign” into “王朝(wang chao)" aims to disclose the plot that these new characters want to take Superman's place and keep control of the world in the Chinese way, making the film title more appealing to viewers.

2) C-E Translation

With the constant import of Chinese culture, the western society gradually welcome and are fascinated by it. Such phenomenon is usually taken into account in C-E translation. For instance, the Chinese animated film 《美食大冒险之 英雄烩(mei shi da mao xian zhi ying xiong hui)》 tells a story that Bao Qiang, an innocent and passionate steamed stuffed bun who has poor martial arts, goes through untold hardships and finally grows into a great hero who saves the world of foods. Since the film includes the elements of Chinese food and Kong Fu which are quite popular among westerners, its English name comes to be "Kungfood". Such translation not only arouses foreign viewers' interest based on their love for Chinese Wushu and food culture, but also grasps an opportunity to show the world the splendid Chinese culture.

\section{Adaptive Selection and Transformation from Communicative Dimension}

Adaptive selection and transformation from communicative dimension focus on whether the communicative intentions of the author, source language, cultural form and connotation in the source language system are reflected in the target language system. Since animated film titles have the commercial function, translators should make selection and adaptation according to the tastes of target viewers, providing the information they want to know and making sure the translation is interesting and enchanting.

1) E-C Translation

Most English animated films choose the names of main characters or a place without any descriptions or just an adjective as their titles, while Chinese ones tend to use descriptive expressions like “历险记(li xian ji)”, “奇缘(qi yuan)" and “大冒险(da mao xian)". In terms of the informative function of film titles, basic information about the characters, plot or theme needs to be added during the E-C translation process. For example, if "The Grinch" was translated as “格林奇(ge lin qi)”, the audience would get confused of the identity of Grinch. The translation “绿毛怪格 林奇(lv mao guai ge lin qi)” seems much better because it makes the proper modification, and arouses people’s curiosity about the story of a green-haired monster. The title translation of popular Disney film Frozen is also successful. Although the word "frozen" perfectly describes the world of ice and snow, it is not suitable for the Chinese film title to choose an adjective again. “冰雪奇缘(bing xue qi yuan)” keeps the elements of winter and adds the color of fantasy, being attractive to children and teenagers.

2) C-E Translation

English animated film titles emphasize directness and information expression, which is a guidance for C-E translation. To give a good case, the title of 《神秘世界历险记(shen mi shi jie li xian ji) 4》 consists of two parts, secret world and adventure. Its translation, "Yugo \& Lala IV", uses the names of main characters which are also the key clues of the film, concise and direct. Another example is the English name of 《阿唐奇遇(a tang qi yu)》, “Tea pets”, which ignores “奇遇(qi yu)” and highlights the identity of “阿唐(a tang)”.

\section{Possible Translation Strategies of Animated Film Titles And FreQuency of Their USE}

According to He Ying (2001), translation methods of film titles are mainly transliteration, literal translation, free translation and creative translation. This part will analyze these four methods from the perspective of Eco-translatology based on the sample and try to find out the frequent translation strategies adopted by the recent animated film titles.

\section{A. Transliteration}

Transliteration means to convert words from one language to another language with a close approximation in 
phonetic sound. It is generally used in films that adopted proper nouns, such as the names of people, places and things that reflect the unique culture of the nation, as film titles (Zhou Hairong, 2009). One culture may contain some particular meanings which are difficult to be conveyed into another culture and understood by target audiences. Some words cannot be translated into another language due to the cultural differences. Transliteration can solve these problems and spread the source culture to a certain extent, achieving the transformation from cultural dimension. For instance, “江南(jiang nan)” is rendered as “Kiangnan”, and “大护法(da hu fa)” as “Da Hu Fa”. In many situations, in effect, animated film titles with person names adopt the combination of transliteration and other translation methods. There are examples like “巧虎大飞船历险记(qiao hu da fei chuan li xian ji)” (“Qiaohu and the Fantastic Flying Ship”), “Klaus” (“克劳斯：圣诞节的秘密 ke lao si: sheng dan jie de mi mi”), and “Paddington 2” (“帕丁顿熊 pa ding dun xiong 2").

As shown in Table II, 23 out of 94 English animated film titles and 6 out of 43 Chinese ones use this translation strategy.

TABLE II

Frequency And Percentage Of TRAnSLiteration

\begin{tabular}{|c|c|c|}
\hline & Frequency & Percentage \\
\hline E-C translation & 23 & $24.5 \%$ \\
\hline C-E translation & 6 & $14.0 \%$ \\
\hline
\end{tabular}

\section{B. Literal Translation}

Due to the limitation of length and content of film titles, literal translation, equated with word-to-word translation, is a practical strategy applied in film title translation. It can not only be faithful to the source text, but also present the original linguistic style thoroughly. The animated film titles often use simple words for the public's better understanding. If simple words can be informative and attractive to viewers, literal translation is undoubtedly a good strategy for both C-E and E-C translation. The animated film 《幸福路上(xing fu lu shang)》is a good case, for its title suggests the location where the story takes place, the "Happiness Road" in Taipei, as well as the plot that the protagonist keeps pursuing happiness. Its translation "On Happiness Road" can fully achieve the three-dimensional transformations. There are more examples for literal translation: “恐龙王(kong long wang)” (“Dino King”), “白鸟(bai niao)” (“White Bird”), “Lady and the Tramp” (“小姐与流浪汉 xiao jie yu liu lang han”), and “Ugly Dolls” (“丑娃娃 chou wa wa").

As shown in Table III, 22 out of 94 English animated films and 7 out of 43 Chinese ones are translated literally.

TABLE III

FREQUENCY AND PERCENTAGE OF LITERAL TRANSLATION

\begin{tabular}{|c|c|c|}
\hline & Frequency & Percentage \\
\hline E-C translation & 22 & $23.4 \%$ \\
\hline C-E translation & 7 & $16.3 \%$ \\
\hline
\end{tabular}

\section{Free Translation}

In most cases, because of the linguistic, cultural and aesthetic differences, it is impossible to simply translate Chinese film titles through transliteration or literal translation. Free translation, as a more flexible translation approach, can solve this dilemma. To achieve the three-dimensional transformations, translators should consider a series of factors and make adjustments to the source film titles, trying to reveal their deep cultural connotation and meanings.

According to Table IV, 63 out of 94 English animated film titles and 32 out of 43 Chinese ones choose free translation as the translation strategy.

TABLE IV

Frequency And Percentage Of Free Translation

\begin{tabular}{|c|c|c|}
\hline & Frequency & Percentage \\
\hline E-C translation & 63 & $67.0 \%$ \\
\hline C-E translation & 32 & $74.4 \%$ \\
\hline
\end{tabular}

Amplification, omission and conversion are the three commonly-used techniques of free translation.

1) Amplification and Omission

In animated film title translation, sometimes it is necessary to add or delete some of the vocabulary or semantic meanings so as to ensure the perception of the audiences. Since Chinese animated film titles prefer the descriptions of characters or stories while English ones pursue directness and are usually named by characters, the translation techniques of amplification and omission can contribute to the three-dimensional transformations. Amplification means adding some necessary words in order to make the meaning clear and correct; omission means retaining the crucial words related to film stories and deleting the redundant information in source titles. The animated film 《雪人奇缘(xue ren qi yuan)》(Abominable), a co-production by Chinese and American studios, is a good case in point. “奇缘(qi 
yuan)" is added in the Chinese name to form a four-character language structure. In the examples like "The Grinch" (“绿毛怪格林奇 lv mao guai ge lin qi”) and “Paddington 2” (“帕丁顿熊 pa ding dun xiong 2”), the identity of the protagonist is added to achieve the transformation from communicative dimension.

2) Conversion

Apparently there exist differences of language habits between China and English-speaking countries. The Chinese are fond of using verbs while westerners are used to applying nouns and prepositions. In order to meet the foreign audiences' aesthetic requirement and achieve the transformation from linguistic dimension, the translator can use the translation technique of conversion.

\section{Creative Translation}

The concept of "translator-centeredness" is fully reflected here. When the strategies above cannot show the main content of the film or make the title appealing, translators should adopt creative translation, which is to recreate the target title on the basis of the film story instead of the source title, taking a great many factors into consideration and making adaptive selection and transformation accordingly. Such translation strategy can help audiences avoid the difficulties in understanding the target text due to cultural differences, and enhance the charm of the translated title (Zhou Hairong, 2009), so that the transformation from communicative dimension will be successfully achieved.

For example, the title of the black humor animated film 《大世界(da shi jie)》 is rendered as "Have a Nice Day" instead of "The Big World". The film tells an absurd story that the driver Zhang is chased by people with evil intentions due to his robbery of a huge amount of money. Since the story takes place within 24 hours and is tinged with irony, "Have a Nice Day" is selected as the title. By contrast, hardly can "The Big World" reflect the idea and spirit of the film. And “冰雪奇缘(bing xue qi yuan)”, the Chinese name of Frozen is also a good instance adopting creative translation, which is analyzed before.

As shown in Table V, 8 out of 94 English animated film titles and 2 out of 43 Chinese ones adopt this strategy.

TABLE V

Frequency And Percentage Of Creative Translation

\begin{tabular}{|c|c|c|}
\hline & Frequency & Percentage \\
\hline E-C translation & 8 & $8.5 \%$ \\
\hline C-E translation & 2 & $4.7 \%$ \\
\hline
\end{tabular}

\section{E. Further Data Analysis of the Translation Strategies}

In general, the sample of recommended animated film titles released from 2017 to 2019 mainly adopt the four translation strategies, which are transliteration, literal translation, free translation and creative translation. And these strategies can all contribute to the three-dimensional transformations to a certain extent.

Figure 1 shows the overall situation concerning the use of these four translation strategies in animated film title translation. On the whole, around $67.0 \%$ of the English film title cases and $74.4 \%$ of the Chinese ones use free translation. However, other translation strategies are far less frequently used than free translation, their percentage being all less than $30 \%$. And creative translation is the least adopted method according to the figure. Therefore, it can be concluded that free translation is the mainstream to translating both Chinese and English animated film titles whereas creative translation is the least preferred by translators.

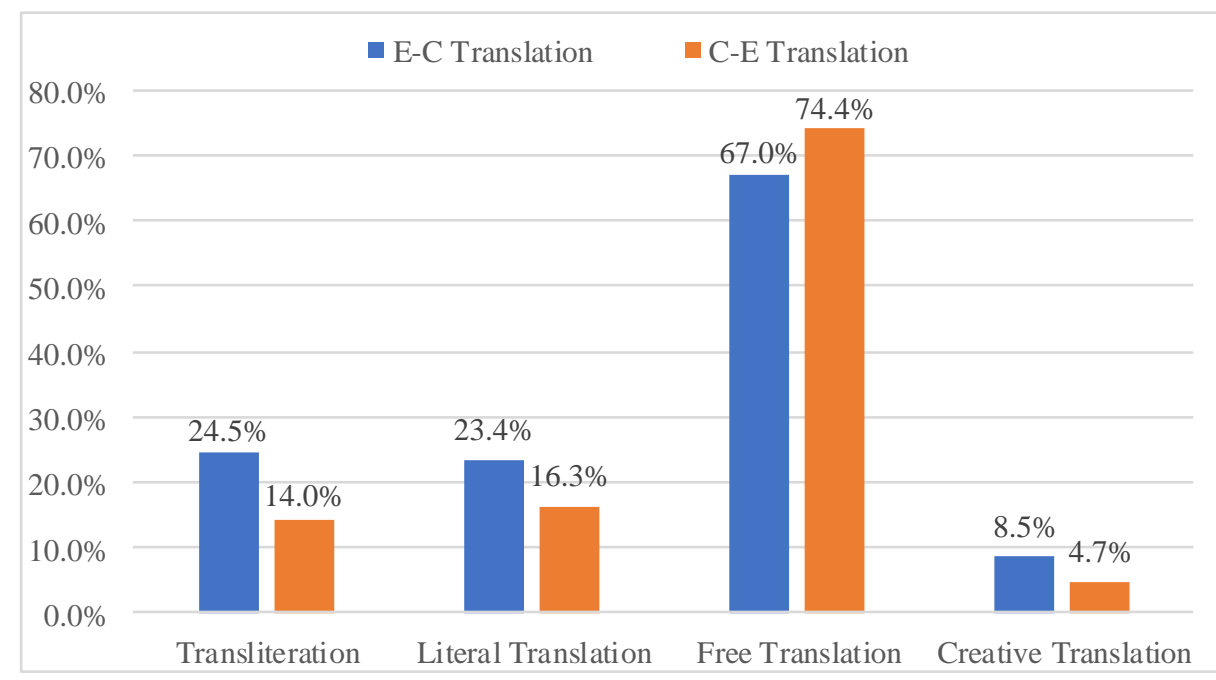

Figure 1. Application of the Four Translation Strategies in Animated Film Title Translation

Animated films are not like other genres. Their main target audiences are children and teenagers, so film titles tend to 
be simple and straightforward. The source titles usually offer the basic information of the films which can be fully accepted by foreign audiences, so in some cases transliteration and literal translation are used to achieve the transformation. Due to various factors in the translational eco-environment of Chinese and English animated film title translation, free translation is always adopted to make some adjustments. However, in most situations, there is no need to use creative translation. That's why it is the least frequently used translation strategy.

\section{CONCLUSION}

As an increasing number of English animated films are introduced and high-quality Chinese films are produced, the animated film industry is paid more and more attention to. The film title, as an eye-catching element of a film, has a guiding effect and plays an important part. In the area of animated film title translation, Eco-translatology is a perfect translation theory that can guide the translation activity. It helps the translators take different factors of the translational eco-environment into consideration and achieve multi-dimensional transformations. Based on the data analysis of the research sample, it is found that free translation is the mainstream to translating both Chinese and English animated film titles while creative translation is the least frequently used method. This study serves as a basis for future studies on animated film title translation, aiming to urge more scholars and researchers to pay attention to animated film title translation and provide support for the development of the industry, with the hope that more and more excellent English animated films can be introduced and that Chinese ones can be produced and seen by the rest of the world.

APPENDiX A. THE COLLECTION OF ENGLish ANimATEd FiLm TitLES

\begin{tabular}{|c|c|c|c|c|}
\hline No. & Source text & Target text & Year of release & Score \\
\hline 1 & Spies in Disguise & 变身特工 & 2019 & 7.7 \\
\hline 2 & Frozen II & 冰雪奇缘 2 & 2019 & 7.2 \\
\hline 3 & Lady and the Tramp & 小姐与流浪汉 & 2019 & 6.8 \\
\hline 4 & The Addams Family & 亚当斯一家 & 2019 & 6.6 \\
\hline 5 & Wonder Woman: Bloodlines & 神奇女侠: 血脉 & 2019 & 5.9 \\
\hline 6 & The Death and Return of Superman & 超人之死与超人归来 & 2019 & 6.7 \\
\hline 7 & Shaun the Sheep Movie: Farmageddon & 小羊肖恩 2: 末日农场 & 2019 & 8.0 \\
\hline 8 & Teen Titans Go! vs Teen Titans & 少年泰坦出击大战少年泰坦 & 2019 & 8.4 \\
\hline 9 & Abominable & 雪人奇缘 & 2019 & 7.3 \\
\hline 10 & Steven Universe The Movie & 宇宙小子大电影 & 2019 & 7.7 \\
\hline 11 & Marvel Rising: Battle of the Bands & 漫威崛起: 乐队之战 & 2019 & 5.6 \\
\hline 12 & Invader ZIM: Enter the Florpus & 外星入侵者 ZIM: 魔幻入口 & 2019 & 5.7 \\
\hline 13 & The Angry Birds Movie 2/ Angry Birds 2 & 愤怒的小鸟 2 & 2019 & 7.0 \\
\hline 14 & $\begin{array}{c}\text { Playmobil: The Movie/ Playmobil: } \\
\text { Robbers, Thieves \& Rebels }\end{array}$ & 摩比小子大电影 & 2019 & 5.8 \\
\hline 15 & $\begin{array}{c}\text { LEGO DC Batman: Family Matters/ LEGO } \\
\text { DC: Batman - Family Matters }\end{array}$ & 乐高 DC 蝙蝠侠：家族事务 & 2019 & 7.1 \\
\hline 16 & Batman: Hush & 蝙蝠侠: 缄默 & 2019 & 6.3 \\
\hline 17 & Toy Story 4 & 玩具总动员 4 & 2019 & 8.6 \\
\hline 18 & The Secret Life of Pets 2 & 爱宠大机密 2 & 2019 & 7.0 \\
\hline 19 & Batman Vs. Teenage Mutant Ninja Turtles & 蝙蝠侠大战忍者神龟 & 2019 & 7.3 \\
\hline 20 & Klaus & 克劳斯：圣诞节的秘密 & 2019 & 8.6 \\
\hline 21 & Ugly Dolls & 丑娃娃 & 2019 & 5.4 \\
\hline 22 & The Pilgrim's Progress & 天路历程 & 2019 & 8.9 \\
\hline 23 & Missing Link & 遗失的环节 & 2019 & 6.7 \\
\hline 24 & Marvel Rising: Heart of Iron & 漫威崛起: 钢铁之心 & 2019 & 5.7 \\
\hline 25 & Justice League vs. The Fatal Five & 正义联盟大战致命五人组 & 2019 & 6.3 \\
\hline 26 & Wonder Park & 神奇乐园历险记 & 2019 & 6.3 \\
\hline 27 & The Lego Movie 2: The Second Part & 乐高大电影 2 & 2019 & 6.6 \\
\hline 28 & Marvel Rising: Chasing Ghosts & 漫威崛起: 幽灵蜘蛛 & 2019 & 5.9 \\
\hline 29 & Reign of the Supermen & $\begin{array}{l}\text { 超人王朝 } \\
\end{array}$ & 2019 & 6.9 \\
\hline 30 & $\begin{array}{c}\text { How to Train Your Dragon: The Hidden } \\
\text { World }\end{array}$ & 驯龙高手 3: 隐秘的世界 & 2019 & 7.4 \\
\hline 31 & Spider-Man: Into the Spider-Verse & 蜘蛛侠: 平行宇宙 & 2018 & 8.6 \\
\hline 32 & Neo Yokio: Pink Christmas & 凯斯： 粉色圣诞节 & 2018 & 6.3 \\
\hline 33 & Ralph Breaks the Internet & 无敌破坏王 2: 大闹互联网 & 2018 & 8.1 \\
\hline 34 & $\begin{array}{l}\text { The Grinch } \\
\end{array}$ & 绿毛怪格林奇 & 2018 & 6.3 \\
\hline 35 & Constantine City of Demons: The Movie & 康斯坦丁: 恶魔之城 电影版 & 2018 & 7.5 \\
\hline 36 & DC Super Hero Girls: Legends of Atlantis & $\begin{array}{c}\mathrm{DC} \text { 超级英雄美少女：亚特兰 } \\
\text { 蒂斯传奇 }\end{array}$ & 2018 & 6.6 \\
\hline 37 & Marvel Rising: Secret Warriors & 漫威崛起: 秘密勇士 & 2018 & 5.4 \\
\hline 38 & Smallfoot & 雪怪大冒险 & 2018 & 7.4 \\
\hline
\end{tabular}




\begin{tabular}{|c|c|c|c|c|}
\hline 39 & Freedom Fighters - The Ray & 自由战士: 射线 电影版 & 2018 & 5.7 \\
\hline 40 & $\begin{array}{c}\text { Lego DC Comics Super Heroes: Aquaman - } \\
\text { Rage of Atlantis }\end{array}$ & $\begin{array}{c}\text { 乐高 DC 超级英雄: 亚特兰蒂 } \\
\text { 斯之怒 }\end{array}$ & 2018 & 6.4 \\
\hline 41 & Teen Titans Go! To the Movies & 少年泰坦出击电影版 & 2018 & 8.2 \\
\hline 42 & The Death of Superman & 超人之死 & 2018 & 7.4 \\
\hline 43 & Adventure Time: Diamonds and Lemons & 探险活宝之钻石与柠檬 & 2018 & 9.0 \\
\hline 44 & Hotel Transylvania 3: Summer Vacation & 精灵旅社 3: 疯狂假期 & 2018 & 6.7 \\
\hline 45 & Incredibles 2 & 超人总动员 2 & 2018 & 7.9 \\
\hline 46 & Batman Ninja & 忍者蝙蝠侠 & 2018 & 7.0 \\
\hline 47 & Suicide Squad: Hell to Pay & 自杀小队: 严厉惩罚 & 2018 & 7.4 \\
\hline 48 & Isle of Dogs & 犬之岛 & 2018 & 8.3 \\
\hline 49 & Lego DC Comics Super Heroes: The Flash & 乐高 DC 超级英雄: 闪电侠 & 2018 & 7.6 \\
\hline 50 & Batman: Gotham by Gaslight & 蝙蝠侠: 煤气灯下的哥谭 & 2018 & 6.8 \\
\hline 51 & $\begin{array}{l}\text { Scooby-Doo \& Batman: the Brave and the } \\
\text { Bold }\end{array}$ & 史酷比与蝙蝠侠: 英勇无畏 & 2018 & 6.6 \\
\hline 52 & $\begin{array}{c}\text { Thomas \& Friends: Big World! Big } \\
\text { Adventures! The Movie }\end{array}$ & 托马斯大电影之世界探险记 & 2018 & 7.1 \\
\hline 53 & Captain Morten and the Spider Queen & 莫滕船长与蜘蛛女王 & 2018 & 6.4 \\
\hline 54 & Sherlock Gnomes & 淘气大侦探 & 2018 & 6.8 \\
\hline 55 & Early Man & 无敌原始人 & 2018 & 6.3 \\
\hline 56 & Charming & 白马王子 & 2018 & 6.0 \\
\hline 57 & Sgt. Stubby: An American Hero & 斯塔比中士: 一个美国英雄 & 2018 & 7.2 \\
\hline 58 & Gnome Alone & 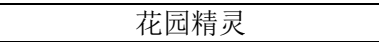 & 2018 & 5.1 \\
\hline 59 & $\begin{array}{l}\text { Luis \& the Aliens/ Luis and His Friends } \\
\text { from Outer Space }\end{array}$ & 三俊闹地球 & 2018 & 6.4 \\
\hline 60 & Ferdinand & 公牛历险记 & 2017 & 7.3 \\
\hline 61 & Game of Thrones: Conquest and Rebellion & 权力的游戏: 征服与反抗 & 2017 & 7.8 \\
\hline 62 & $\begin{array}{l}\text { The Star } \\
\end{array}$ & $\begin{array}{l}\text { 圣诞星 } \\
\end{array}$ & 2017 & 6.4 \\
\hline 63 & Paddington 2 & 帕丁顿熊 2 & 2017 & 8.1 \\
\hline 64 & Michael Jackson's Halloween & 迈克尔·杰克逊的万圣节 & 2017 & 5.2 \\
\hline 65 & Coco & 寻梦环游记 & 2017 & 9.1 \\
\hline 66 & Batman Vs. Two-Face & 蝙蝠侠大战双面人 & 2017 & 5.7 \\
\hline 67 & My Little Pony: The Movie & 小马宝莉大电影 & 2017 & 6.9 \\
\hline 68 & The Lego Ninjago Movie & 乐高幺影忍者大电影 & 2017 & 6.4 \\
\hline 69 & Barbie Dolphin Magic & 芭比之海豚魔法 & 2017 & 7.4 \\
\hline 70 & Starship Troopers: Traitor of Mars & 星河战队: 火星叛国者 & 2017 & 5.9 \\
\hline 71 & The Nut Job 2: Nutty by Nature & 抢劫坚果店 2 & 2017 & 6.2 \\
\hline 72 & The Emoji Movie & 表情奇幻冒险 & 2017 & 5.2 \\
\hline 73 & Lego Scooby-Doo! Blowout Beach Bash & 乐高史酷比: 沙滩狂欢派对 & 2017 & 5.3 \\
\hline 74 & Batman and Harley Quinn & 蝙蝠侠与哈莉·奎恩 & 2017 & 6.7 \\
\hline 75 & $\begin{array}{l}\text { Tom and Jerry: Willy Wonka and the } \\
\text { Chocolate Factory }\end{array}$ & $\begin{array}{c}\text { 猫和老鼠: 查理与巧克力工 } \\
\text { 厂 } \\
\end{array}$ & 2017 & 5.9 \\
\hline 76 & Cars 3 & 赛车总动员 3: 极速挑战 & 2017 & 7.0 \\
\hline 77 & Despicable Me 3 & 神偷奶爸 3/ 卑鄙的我 3 & 2017 & 6.8 \\
\hline 78 & Magical Circus: Animal Crackers & 神奇马戏团之动物饼干 & 2017 & 5.7 \\
\hline 79 & Captain Underpants: The First Epic Movie & 内裤队长 & 2017 & 5.6 \\
\hline 80 & Vixen: The Movie & 雌狐: 大电影 & 2017 & 5.9 \\
\hline 81 & Teen Titans: The Judas Contract & 少年泰坦: 犹大契约 & 2017 & 6.7 \\
\hline 82 & Smurfs: The Lost Village & 蓝精灵: 寻找神秘村 & 2017 & 6.3 \\
\hline 83 & The Boss Baby & $\begin{array}{c}\text { 宝贝老板 } \\
\end{array}$ & 2017 & 7.5 \\
\hline 84 & Tangled: Before Ever After & 魔发奇缘: 幸福前奏 & 2017 & 6.6 \\
\hline 85 & Richard the Stork/ A Stork's Journey & 理查大冒险 & 2017 & 6.5 \\
\hline 86 & The Lego Batman Movie & 乐高蝙蝠侠大电影 & 2017 & 8.0 \\
\hline 87 & Justice League Dark & 黑暗正义联盟 & 2017 & 7.4 \\
\hline 88 & Barbie Video Game Hero & 芭比之游戏英雄 & 2017 & 6.5 \\
\hline 89 & Surf's Up 2: WaveMania & 冲浪季节 2/ 冲浪企鹅 2 & 2017 & 5.8 \\
\hline 90 & The Little Vampire 3D & 精灵小王子 & 2017 & 6.4 \\
\hline 91 & Happy Family & 精灵怪物: 疯狂之旅 & 2017 & 5.3 \\
\hline 92 & Loving Vincent & 至爱梵高·星空之谜 & 2017 & 8.5 \\
\hline 93 & The Breadwinner & 养家之人 & 2017 & 8.4 \\
\hline 94 & Kapture-Fluke & 卡普炔: 福禄克 & 2017 & 6.1 \\
\hline
\end{tabular}


Appendix B. The Collection of Chinese Animated Film Titles

\begin{tabular}{|c|c|c|c|c|}
\hline No. & Source Text & Target Text & Year of Release & Score \\
\hline 1 & 江南 & Kiangnan & 2019 & 7.7 \\
\hline 2 & 雪人奇缘 & Abominable & 2019 & 7.2 \\
\hline 3 & 继园台七号 & No. 7 Cherry Lane & 2019 & 6.8 \\
\hline 4 & 罗小黑战记 & The Legend of Hei & 2019 & 6.6 \\
\hline 5 & 全职高手之巅峰荣耀 & The King's Avatar: For the Glory & 2019 & 5.9 \\
\hline 6 & 哪吒之魔童降世 & Ne Zha / Nezha: Birth of the Demon Child & 2019 & 6.7 \\
\hline 7 & 巧虎大飞船历险记 & Qiaohu and the Fantastic Flying Ship & 2019 & 8.0 \\
\hline 8 & 江海渔童之巨龟奇缘 & A Fishboy's Story: Tortoise from the Sea & 2019 & 8.4 \\
\hline 9 & 动物方言 & Breathless Animals & 2019 & 7.3 \\
\hline 10 & 熊出没·原始时代 & Boonie Bears: Blast into the Past & 2019 & 7.7 \\
\hline 11 & 白蛇: 缘起 & White Snake & 2019 & 5.6 \\
\hline 12 & 西幽玹歌 & Thunderbolt Fantasy & 2019 & 5.7 \\
\hline 13 & 恐龙王 & Dino King & 2019 & 7.0 \\
\hline 14 & 昨日青空 & Crystal Sky of Yesterday & 2019 & 5.8 \\
\hline 15 & 大闹西游 & Monkey Magic / Adventure in Journey to the West & 2019 & 7.1 \\
\hline 16 & 未来机器城 & Next Gen & 2019 & 6.3 \\
\hline 17 & 美食大冒险之英雄烩 & Kungfood & 2019 & 7.3 \\
\hline 18 & $\begin{array}{c}\text { 肆式青春 } \\
\end{array}$ & Flavors of Youth & 2019 & 8.6 \\
\hline 19 & 风语咒 & The Wind Guardians & 2019 & 7.0 \\
\hline 20 & 神秘世界历险记 4 & Yugo \& Lala IV & 2019 & 7.3 \\
\hline 21 & 女他 & $\mathrm{SHe}$ & 2019 & 8.6 \\
\hline 22 & 吃货宇宙 & Foodiverse & 2019 & 5.4 \\
\hline 23 & 空气侠 & Air Man / NOT HERO & 2019 & 8.9 \\
\hline 24 & 猫与桃花源 & Cats and Peachtopia & 2019 & 6.7 \\
\hline 25 & 妈妈咪鸭 & Duck Duck Goose & 2019 & 5.7 \\
\hline 26 & 熊出没·变形记 & Boonie Bears: The Big Shrink & 2019 & 6.3 \\
\hline 27 & 金龟子 & The Ladybug & 2019 & 6.3 \\
\hline 28 & 穿颖透写 & Lacuna & 2019 & 6.6 \\
\hline 29 & 钟馗传奇之岁寒三友 & Judge Zhongkui & 2019 & 5.9 \\
\hline 30 & 昆塔: 反转星球 & $\begin{array}{c}\text { Axel: Adventures of the Spacekids / The Floating } \\
\text { Planet }\end{array}$ & 2019 & 6.9 \\
\hline 31 & 拾梦老人 & The Dream Collector & 2019 & 7.4 \\
\hline 32 & 十万个冷笑话 2 & One Hundred Thousand Bad Jokes II & 2018 & 8.6 \\
\hline 33 & 玩偶奇兵 & T-Guardians & 2018 & 6.3 \\
\hline 34 & 豆福传 & Tofu & 2018 & 8.1 \\
\hline 35 & 大护法 & $\mathrm{Da} \mathrm{Hu} \mathrm{Fa}$ & 2018 & 6.3 \\
\hline 36 & 阿唐奇遇 & Tea Pets & 2018 & 7.5 \\
\hline 37 & 白鸟 & White Bird & 2018 & 6.6 \\
\hline 38 & 大世界 & Have a Nice Day & 2018 & 5.4 \\
\hline 39 & 萤火奇兵 & Lighting Dindin & 2018 & 7.4 \\
\hline 40 & 熊出没·奇幻空间 & Bonnie Bears: Entangled Worlds & 2018 & 5.7 \\
\hline 41 & 猪猪侠之英雄猪少年 & GG Bond: Guarding & 2018 & 6.4 \\
\hline 42 & 生死一剑 & $\begin{array}{l}\text { Thunderbolt Fantasy: The Sword of Life and } \\
\text { Death }\end{array}$ & 2018 & 8.2 \\
\hline 43 & 幸福路上 & On Happiness Road & 2018 & 7.4 \\
\hline
\end{tabular}

\section{ACKNOWLEDGMENTS}

The current work is supported by grant CFTD203032 from Center of Faculty Teaching Development, University of Shanghai for Science and Technology, and grant from College of Foreign Languages, University of Shanghai for Science and Technology.

\section{REFERENCES}

[1] Bassnett, S. \& Lefevere, A. (1990). Translation, history and culture. London: Pinter Publishers.

[2] Cronin, M. (2003). Translation and globalization. London: Routledge.

[3] He, Ying. (2001). On the translation of movie titles. Foreign Language Education, 01, 56-60.

[4] Hu, Gengshen. (2001) (unpublished). An initial exploration into an approach to translation as adaptation and selection. Hong Kong: 3rd FIT Asian Translators' Forum.

[5] Hu, Gengshen. (2008). Eco-translatology: A primer. Chinese Translators Journal, 6, 11-15.

[6] Hu, Gengshen. (2013). Eco-translatology: Construction \& interpretation. Beijing: The Commercial Press. 
[7] Li, Qun. (2002). The subversion of "faithfulness" in film title translation - its current situation and theoretical basis (pian ming fan yi dui "zhong shi" de dian fu - dian ying pian ming fan yi de xian zhuang ji li lun yi ju). Journal of Beijing International Studies University, 05, 41-45.

[8] Newmark, P. (1982). Approaches to translation. Oxford: Pergamon.

[9] Nord, C. (2006). Text analysis in translation: Theory, methodology, and didactic application of a model for translation-oriented text analysis (2nd edn.). Beijing: Foreign Language Teaching and Research Press.

[10] Wang, Hongxi. (2019). Comparison and translation of English and Chinese animated film titles (ying han dong hua dian ying pian ming dui bi yu fan yi). PR Magazine, 11, 261-263.

[11] Zhou, Hairong. (2009). Study on principles and methods of Chinese film title translation (zhong wen dian ying pian ming ying yi yuan ze he fang fa yan jiu). Journal of Educational Institute of Jilin Province, 25.08, 116-117.

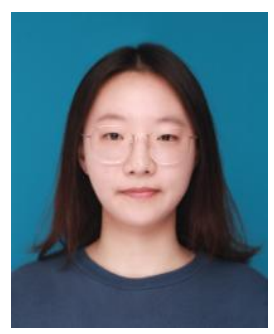

Yue Wang was born in Shanghai, China on 12 November 1997. She graduated from University of Shanghai for Science and Technology (USST) in Shanghai, China with a Bachelor of Arts in English in June 2020. She will continue to study for a Master of Arts degree in English language and literature at Shanghai International Studies University (SISU) in Shanghai, China.

She had two internships. The first one was in the summer of 2018 when she interned as a Junior Copywriter in a media company. She then worked as a CRM Marketing Consulting Intern in 2019, mainly making and translating proposals. Her final thesis of undergraduate was named an outstanding thesis of USST in 2020. Her current research interest is translation studies. She can be reached through linda3z@qq.com.

Xiaowen Ji was born in China in 1991. She obtained her Master's degree in English Language and Literature from Shanghai International Studies University (SISU) in 2014, and her PhD degree in the same major from the same university in 2017, with a year as a visiting $\mathrm{PhD}$ researcher in Leiden University, the Netherlands, supported by China Scholarship Council.

She is currently a lecturer in University of Shanghai for Science and Technology. Her research interests include multilingual development, interpreting studies, and teaching of English as a second language. She can be reached through jixiaowensisu@163.com. 